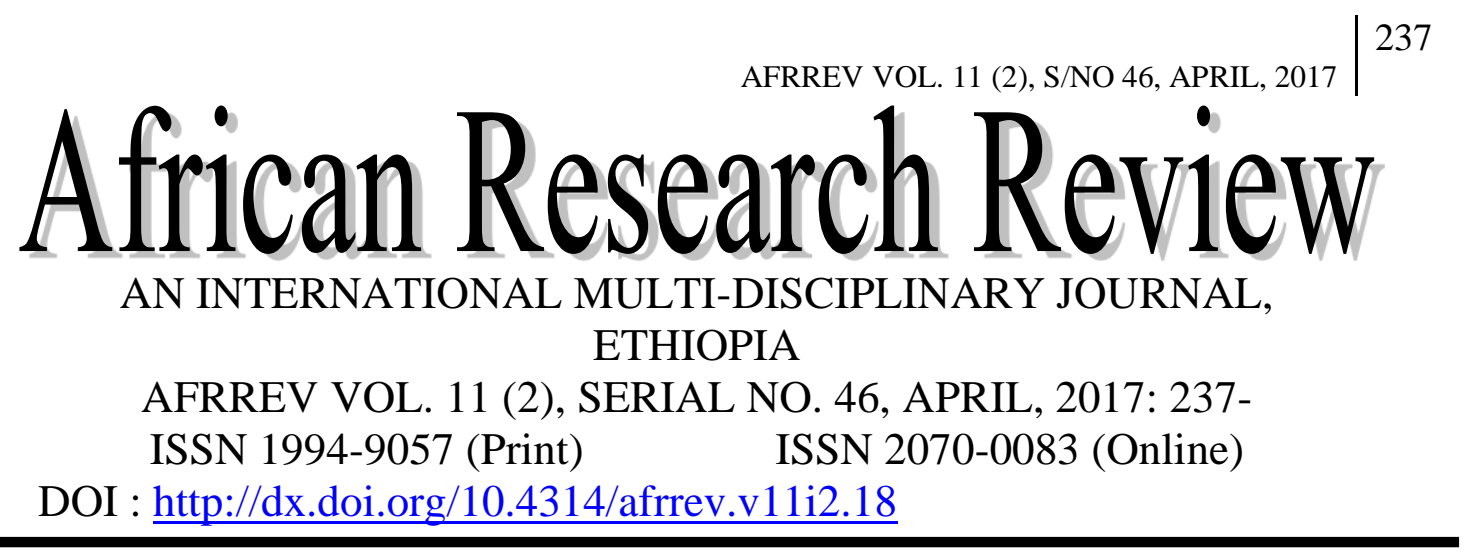

\title{
The Impact of Microteaching in Developing Teaching Skills among Pre-Service Teachers in Alvan Ikoku College of Education Owerri, Nigeria
}

\author{
Onwuagboke, Bede Blaise Chukwunyere \\ Department of Curriculum \& Instruction \\ Alvan Ikoku Federal College of Education, Owerri, \\ Imo State, Nigeria \\ E-mail: bbconwu@gmail.com
}

\section{Osuala, Rita Chigozie}

Department of Psychology /Guidance and Counselling Alvan Ikoku Federal College of Education Owerri, Nigeria

\section{Nzeako, Rowland Chibuike}

Department of Curriculum \& Instruction

Alvan Ikoku Federal College of Education, Owerri

Imo State, Nigeria

\section{Abstract}

Teaching skills are necessary tools teachers should possess for effectiveness in their job. Teaching the teacher candidates these skills is not simple hence the need for a microteaching environment which enables pre-service teachers to acquire them under controlled laboratory setting. This study was an extension of current NCE microteaching programme run by Alvan Ikoku College of Education for the B.Ed.

Copyright () International Association of African Researchers and Reviewers, 2006-2017:

$$
\text { www.afrevjo.net. }
$$

Indexed African Journals Online: www.ajol.info 
student teachers in order to determine its impact on their acquisition of the requisite teaching skills. A sample of 90 student teachers was purposively drawn from the second-year degree students in the college who were preparing to embark on the teaching practice programme in the 2016 teaching practice programme. The study involved a pre-test and a post-test of the students using a microteaching skills rating scale (MSRS) developed by the researchers. Data collected was analysed using descriptive and inferential statistics. The findings of the study revealed that the microteaching interventions improved the teaching skills significantly with significant differences between the three intervention groups. The group that received microteaching treatment with video recording performed better than the other groups while gender had no significant effect on their mean scores. The result has far reaching implication on the need for a well-equipped microteaching laboratory for microteaching programmes in teacher education institutions.

Key Words: Impact; microteaching; teaching skills; pre-service teachers

\section{Introduction}

Teaching a teacher how to teach in the classroom has never been an easy task in the teacher education programme. Prior to the development of microteaching, several methods have been employed in training teachers. One of such technique is the observation of a master teacher after which the trainee teacher goes to teach. The other method is the trial-and-error method in which the teacher trainee acquires teaching skills in his own teaching sessions (Remesh, 2013). These two approaches have their flaws as both good and bad teacher behaviours are copied from the master teacher as the trainee teacher is unaware of the desired teacher behaviours to copy and develop (Ike, 2017).

Microteaching was initially developed in Stanford University in early 1960's by Dwight Allen and his colleagues as an experimental programme with the aim of achieving excellence in teacher education (Ifegbo, 2012; Ike, 2017; Wei, 2015). Microteaching is organized practice teaching which is aimed at giving instructors confidence, support, and feedback by allowing them try out among friends and colleagues a short segment of what they plan to do with their pupils (Harvard University, 2006). It is considered one of the most effective tools in bridging the gap between theory and practice of teaching (Adedapo, 2013; Ghanaguru, Nair \& Yong, 2013). It is a scaled down teaching encounter in terms of time, class size (number of students) and teaching complexity (Abifarin, 2004; Adewoyin, 2007; Cruickhank et al., 1996; Ike, 2017). In terms of time, microteaching is carried out between 5 to 10 minutes, in terms of class size; 5-10 students are involved whereas one teaching skill is involved at a time. The content of the teaching encounter is also reduced to a concept rather than a topic (Ike, 2017; Otsupius, 2014). In a nutshell, microteaching can be perceived as an important instructional means that mediates between educational

Copyright $\odot$ International Association of African Researchers and Reviewers, 2006-2017: www. afrrevjo.net.

Indexed African Journals Online: www.ajol.info 
theory and practice (Benton-Kupper, 2001; Esiobu \& Maduekwe, 2008; Wahba, 1999). Microteaching is a teacher education course designed to equip the would-be teachers with the teaching skills and competencies needed to perform as effective teachers in their chosen profession (Mayhew, 1982).

The advantages of microteaching are numerous. It has the advantage of allowing the pre-service teachers to practice specific teaching strategies in a supportive, nonthreatening laboratory environment. It also enables them to receive immediate detailed feedback to reinforce their didactic skills. In view of the fact that the microteaching lessons are short, they are focused on teaching strategies rather than content (Ike, 2017). The introduction of microteaching no doubt has helped in overcoming the problem of effective teacher training method to be followed in teacher training programmes (Elliot, 1982). Achieving effectiveness in instructional delivery should be the prime objective of a teacher. As an innovative technique of training teachers to be effective, skills and practices of microteaching needs being implemented in teacher training institutions (Remesh, 2013). Microteaching is a technique of teaching teacher candidates how to teach by identifying, analysing and isolating the various skills involved in teaching so as to practice and acquire them singly. By so doing, learning of each skill is ensured as the student teacher is afforded a chance of listening, observing, and practicing (Remesh, 2013).

\section{Theory}

The application of microteaching technique in teacher training provides student teachers a tremendous opportunity to develop their teaching skills. As microteaching is solely concerned with development of good teacher behaviours, this study is based on the theory of behaviourism. Behavioural theorists describe learning as a "semipermanent change in behaviour." They maintain that learning has only taken place if there is an evidence of a change in behaviour. Skinners' theory of operant conditioning is the underpinning theory (Passi, 1976) which stressed the reinforcement of target behaviour and Thorndike law of practice are of great importance in this study. The law stated that the more stimulus response (S-R) bond is practiced, the stronger it will become. Thorndike however modified the law when he discovered that practice without feedback does not necessarily lead to increased performance (Keesee, n.d.). It is in keeping with this that the knowledge of immediate feedback dimension of microteaching is one of the pillars of microteaching as an innovative teacher training programme. In this study, the feedback of student teachers' behaviour during microteaching exercise was provided by the Supervisors, peers and the video recordings in the microteaching laboratory to reinforce and enhance the development of the teaching skills.

Teaching skills are particular teacher behaviours intended to make classroom teaching more efficient. The microteaching skills which pre-service teachers practice include set

Copyright (C) International Association of African Researchers and Reviewers, 2006-2017: www.afrrevjo.net.

Indexed African Journals Online: www.ajol.info 
induction, use of examples stimulus variation, various questioning, re-enforcement, planned repetition, non-verbal communication and closure (Ike, 2017; Williams, 2010). As microteaching is a teaching encounter designed to enable trainee teachers acquire a repertoire of skills needed for effectiveness in the classroom, it remains the most appropriate programme for imparting these skills in the pre-service teacher. The teaching skills acquisition in the microteaching programme follows a cycle which each pre-service teacher goes through to acquire and eternalize the needed teacher behaviours (Ike, 2017; Nazir, 2011). The practice of each skill follows the cycle which is represented diagrammatically in figure 1.

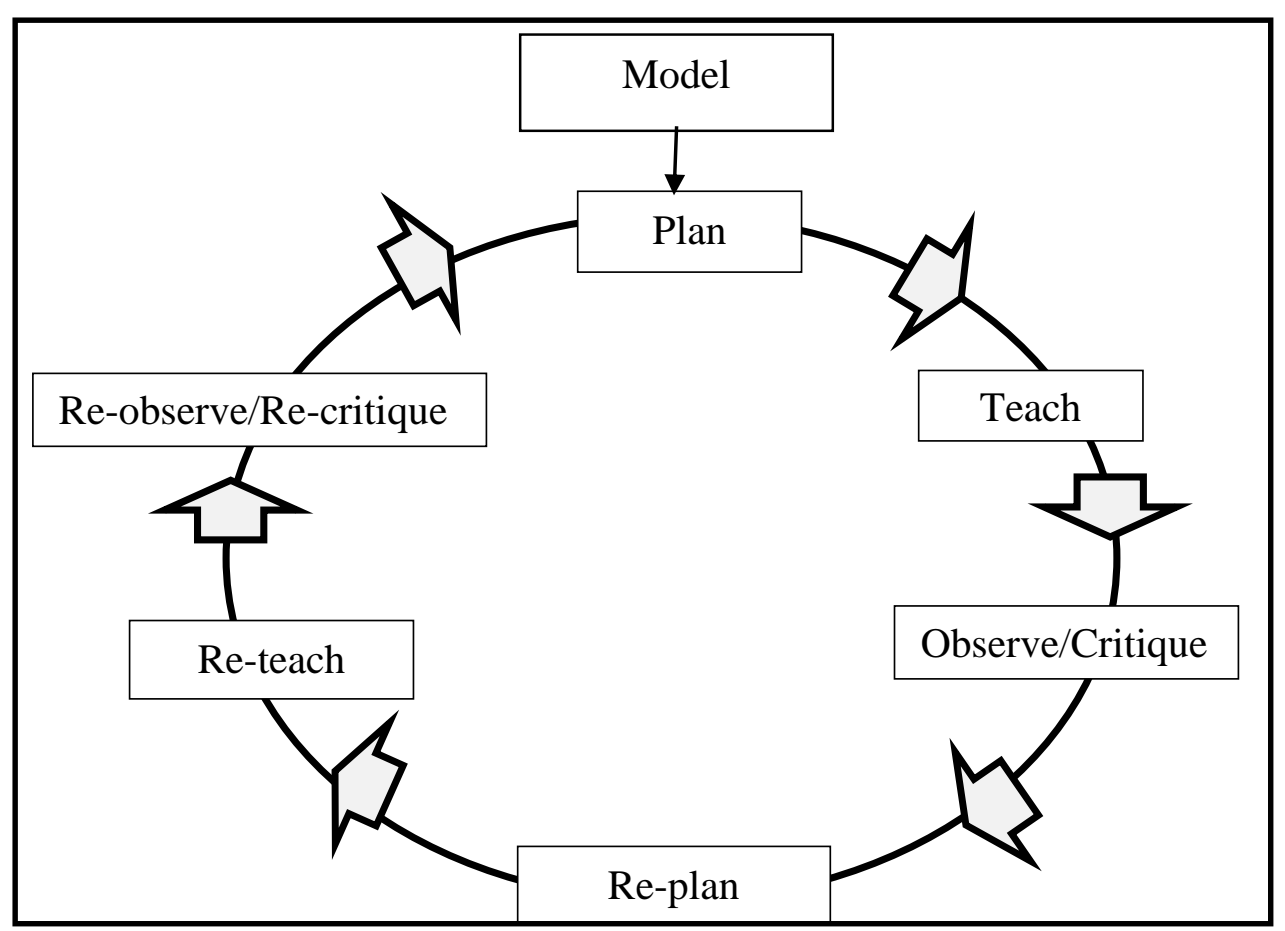

Figure 1: Microteaching Cycle

The cycle begins by the teacher educator modelling the required teaching skill slated for practicing by the pre-service teachers. After observing the modelled skill, the preservice teacher selects the given teaching skill and prepares a lesson plan that will enable him/her practice and exhibit the teacher behaviours characteristic of the given skill. The emphasis in microteaching is not the subject matter mastery but ability to exhibit the given teacher behaviours which are components of a given skill (Ike, 2017). After planning, the pre-service teacher teaches the planned lesson observed by a Supervisor and his peers as well as being video recorded. At the end of the teaching encounter, the lesson is replayed for the pre-service teacher to self-critique himself first

Copyright () International Association of African Researchers and Reviewers, 2006-2017: www. afrrevjo.net.

Indexed African Journals Online: www.ajol.info 
starting from the strong points (Nazir, 2011). The student teachers' self-criticism is followed by feedback from his peers and Supervisor each first praising the strengths before weaknesses. Nazir (2011) maintained that weaknesses already mentioned should not be repeated.

The pre-service teacher re-plans the lesson bearing in mind the corrections and feedback received from his observation of the video playback, peer and supervisor's comments. He re-teaches the lesson and also observed by the Supervisor and his peers. After the teaching exercise, the lesson is re-observed and re-critiqued until the skill is mastered by the student teacher. The cycle can go on depending on availability of time for the programme as Nazir (2011) stated that a research in microteaching reported up to $87 \%$ improvement in 3 cycles and $61 \%$ in 2 cycles. The next teaching skill is selected and practiced accordingly following the same cycle. After the acquisition of all the essential skills the pre-service teacher is expected to be adequately prepared to integrate them for effective teaching in a macro teaching or real classroom-situations (Ike, 2017; Otsupius, 2014).

The integration of video technology into microteaching has been acclaimed to add glamour to and makes the evaluation process more objective, highly reflective, realistic and more practical (Ekpo-Eloma, Arikpo \& Ebuta, 2014). The use of video recording has made the microteaching teaching sessions in the teaching laboratories very attractive to student teachers. Majority of them feel excited to see themselves teaching during the observe/critique session of their practice when a play-back of their teaching is watched. It thus affords them the opportunity to self-critique their practice so as to work towards improving their skills. According to Derek Bok Centre for Teaching and Learning (2002) nearly every student teacher, however, finds it very helpful to book an appointment to view and discuss their video recording together with their supervisors.

Researches on microteaching in the learning environment have been quite few. Some researchers have made attempts to find the effects of aspects of microteaching programmes on teaching effectiveness. For example, Oscar, (2012) examined video tape recorder (VTR) as a tool for the promotion of effective teaching and learning in schools. The result of the investigation revealed that video-tape recorder is a powerful tool that promotes effective teaching and learning in schools. Similarly, Shanu (2016) investigated the impact of microteaching video feedback on student-teachers' performance in teaching practice. Findings of the investigation reveal that student teachers who were exposed to microteaching video feedback performed better in teaching practice than those that were not exposed to it. In a related study, Umeh, Mogbo and Nsofor, (2015) studied the effectiveness of VTR on micro-teaching on student teachers practice of stimulus variation skills. The findings of the study revealed that the use of video tape recorder effectively increased the performance of the preservice teachers who were in the experimental group. Similarly, Savas, (2012) in an

Copyright () International Association of African Researchers and Reviewers, 2006-2017: www. afrrevjo.net.

Indexed African Journals Online: www.ajol.info 
earlier study found that using video recordings of microteaching sessions enhanced the English teaching skills of EFL pre-service teachers in a University in Turkey. Another study carried out in Turkey by Kilic, (2010) revealed that the microteaching model employed in the study enhanced student teachers' teaching behaviours on subject area, planning, teaching process, classroom management, communication, and evaluation.

In a similar but different study, Programindaki and Arastırılmas1 (2009) used a qualitative approach to determine the effectiveness of peer microteaching in teacher education programme in Turkey. Findings revealed that peer microteaching practices, improved self-confidence of the participants as they found the opportunity to observe themselves while gaining experience. Ekpo-Eloma, Arikpo \& Ebuta (2014), in a related study found a significant relationship between the use of video technology and teacher trainees' self-appraisal and evaluation irrespective of gender. Nwana (2010) equally studied the effect of gender on student-teachers' VTR technique acquisition for mastering verbal communication skill in microteaching and concluded gender had no significant effect on student-teachers' acquisition of verbal skills through VTR evaluation.

Effective development of teaching skills in teachers should target the pre-service teachers as they are the future teachers. Incorporating the development of these skills will not only make the use of these skills practicable but also provide a model for actual and seamless implementation of these skills in normal classroom situation. Alvan Ikoku University of Education as a leading institution in teacher education has been functioning as a centre of excellence in educational innovation (Ohuche \& Izuwah, 1988). With a well-established microteaching facility, it is auspicious to investigate the impact of the microteaching on the development teaching skills of pre-service teachers in the university. This is against the backdrop that Ijioma, Obasi and Ifegbo (2014) reiterate that microteaching has not been given prominence in degree teacher education supervised by the Nigeria Universities Commission (NUC).

This was done to provide evidence of the impact of microteaching in developing teacher candidates' teaching skills in the 21 st century and thus provide an empirical evidence for the inclusion of microteaching in degree teacher education programme. The study was designed to extend the peer microteaching model adopted and practiced in Alvan Ikoku College of Education Nigeria Certificate in Education (NCE) programme with a view of finding out its impact in the development of some selected teaching skills by degree pre-service teachers. Compare the effectiveness of 3 different levels of the microteaching approach in enhancing the acquisition of the said teaching skills. The study also tried to determine if gender has any influence in pre-service teachers' microteaching skill development.

Copyright (C) International Association of African Researchers and Reviewers, 2006-2017: www.afrrevjo.net.

Indexed African Journals Online: www.ajol.info 
AFRREV VOL. 11 (2), S/NO 46, APRIL, 2017

\section{Methodology}

The research used a quantitative research paradigm with a pre-test post-test quasiexperimental research design. The study entailed observing the pre-service teachers' teaching skills prior to exposure to microteaching programme. The participants were then exposed to the microteaching programme as designed by the researchers after which they were treated to a post-treatment observation in a normal classroom situation. The study was carried out during the 2015/2016 academic year.

The population comprised of all 200 level bachelor's degree students of the 4-year degree programme of Alvan Ikoku College of Education who were eligible to take the Education Technology course during the 2015/2016 academic year. A sample of 90 students was purposively selected from the population. They were chosen on the basis that they responded to a call for volunteers to participate in a study by the researchers. 30 participants were chosen from each group of students taught by the three teaching teams. The groups are Social science group, Arts group and Science group.

The instrument for data collection was a microteaching skills rating scale (MSRS) adapted from Ike (2017) which was used to rate the pre-service teachers' frequency of exhibition of required skills while teaching. The MSRS is a 23 -item scale which requires the supervisor of the teaching practice to rate the occurrence of required teacher behaviours using never, less frequent, frequent and very frequent. The content validity of the rating scale was ensured by the use of a panel of 3 experts drawn from curriculum and instruction and measurement and evaluation departments from two tertiary institutions in Owerri. The panel checked the correctness and appropriateness of language; relevance and coverage of the items in the instrument to ensure that the items did not go beyond the scope of expected teacher behaviours to be developed by the student teachers. Based on expert advice, the items that were ambiguous were modified while those the panel considered out of the scope of the skills were dropped. The final instrument was trial tested using second year student teachers from a nearby university.

The reliability of the rating scale was established using inter-rater and intra-rater reliability coefficient according to Fleiss (1989) interclass correlation coefficient (ICC). The rating scale achieved an inter-rater reliability coefficient of .81 and intrarater reliability coefficient of .89 and thus considered reliable. The inter-rater reliability was achieved by 3 different raters rating each of the student teachers' exhibiting of the required teaching skills. All the individual scores awarded by the raters constitute the unit of analysis rather than an average measure in accordance with Shrout and Fleiss, (1979). On the other hand, the intra-rater reliability of the rating scale was achieved using one rater to rate all the student teachers at one time. The teaching encounters were recorded and after a week's interval the same rater rated the student teachers again

Copyright (ㅇ International Association of African Researchers and Reviewers, 2006-2017: www. afrrevjo.net.

Indexed African Journals Online: www.ajol.info 
by watching the recordings. The ICC was calculated for the two ratings of the rater taken at two different points in time.

Prior to the intervention, the participants were asked to teach a lesson in the College model secondary school and were observed using the MSRS to assess the level of their teaching skills. Group 1 was exposed to microteaching using digital video recording for feedback. Group 2 was exposed to microteaching in the laboratory without digital video recording feedback but with peer and supervisor feedback while group three received lectures on microteaching skills without laboratory practical (conventional teaching). After the interventions, the pre-service teachers were rated using the teaching skills rating scale during their teaching practice. Never was rated 1, less frequent was rated 2 , frequent was rated 3 while very frequent was rated 4 . The research questions and the research hypotheses for the study were answered and tested using descriptive and inferential statistics. The IBM SPSS software version 22 was used to analyse the data.

\section{Result}

The findings of the study are presented in this section using tables. The result of the study shows that the microteaching exercise carried out by the pre-service teachers significantly improved their teaching skills acquisition. Data displayed on table 1 shows that post-intervention means scores (Mean $=62.66 \mathrm{SD}=7.54)$ of the participants was significantly greater than their pre-intervention means scores (Mean $=48.70 \mathrm{SD}=$ 3.56 ), $\mathrm{t}(89)=17.93, \mathrm{p}<.000$ (two-tailed). The mean increase in teaching skills ratings of the pre-service teachers after undergoing microteaching was 13.96 with a $95 \%$ confidence interval ranging from -12.41 to 15.50 . The eta squared statistic of (.78) indicates a large effect size according to Cohen, (1988).

Table 1: Paired Samples t-test of mean difference between pre-test and post-test microteaching skills mean ratings

\begin{tabular}{llllllll}
\hline S/No. & Time of Test & N & df & Mean & SD & t & Sig. \\
\hline 1. & Mean rating (pre-test) & 90 & 89 & 48.70 & 3.56 & 17.93 & $.000^{* *}$ \\
2. & Mean rating (post-test) & 90 & & 62.66 & 7.54 & & \\
\hline
\end{tabular}

***Indicates significant at 0.05 level

Results also revealed that differences exist in the teaching skills ratings of three groups that took part in the study. For example, table 2 shows that Group A which practiced microteaching in the laboratory with CCTV recordings and playback received a mean rating of 71.2; Group B that practiced microteaching in the laboratory without CCTV recording and playback received a mean rating of 60.13 while the control Group $\mathrm{C}$ which were taught microteaching conventionally without CCTV and laboratory practical received a mean rating of 56.63 .

Copyright $\odot$ International Association of African Researchers and Reviewers, 2006-2017: www. afrrevjo.net.

Indexed African Journals Online: www.ajol.info 
Table 2: Mean ratings of the 3 intervention groups on post-test teaching skills

\begin{tabular}{|c|c|c|c|c|c|c|c|c|}
\hline & \multirow[b]{2}{*}{$\mathrm{N}$} & \multirow[b]{2}{*}{ Mean } & \multirow[b]{2}{*}{$\begin{array}{l}\text { Std. } \\
\text { Deviation }\end{array}$} & \multirow[b]{2}{*}{ Std. Error } & \multicolumn{2}{|c|}{$\begin{array}{l}95 \% \text { Confidence } \\
\text { Interval for Mean }\end{array}$} & \multirow[b]{2}{*}{ Min. } & \multirow[b]{2}{*}{ Max. } \\
\hline & & & & & $\begin{array}{l}\text { Lower } \\
\text { Bound }\end{array}$ & $\begin{array}{l}\text { Upper } \\
\text { Bound }\end{array}$ & & \\
\hline Group A & 30 & 71.2000 & 4.96470 & .90643 & 69.3461 & 73.0539 & 63.00 & 84.00 \\
\hline Group B & 30 & 60.1333 & 4.26480 & .77864 & 58.5408 & 61.7258 & 53.00 & 71.00 \\
\hline Group C & 30 & 56.6333 & 3.48873 & .63695 & 55.3306 & 57.9360 & 52.00 & 68.00 \\
\hline Total & 90 & 62.6556 & 7.54337 & .79514 & 61.0756 & 64.2355 & 52.00 & 84.00 \\
\hline
\end{tabular}

A one-way analysis of variance test was conducted to ascertain if the observed differences are significant statistically. Table 3 shows that there is statistically significant difference in the mean ratings of the three interventions groups as a result of type of intervention: $F(2,87)=94.6, p=.000$. The eta squared statistic of (.68) indicates a large effect size according to Cohen, (1988).

Table 3: Test of significant difference in teaching skills mean rating between the 3 intervention groups

\begin{tabular}{llllll}
\hline \hline & Sum of Squares & df & Mean Square & F & Sig. \\
\hline Between Groups & 3469.089 & 2 & 1734.544 & 94.598 & $.000^{* *}$ \\
Within Groups & 1595.233 & 87 & 18.336 & & \\
Total & 5064.322 & 89 & & & \\
\hline \hline
\end{tabular}

***Indicates significant at 0.05 level

Post-hoc comparisons test using Tukey HSD test was therefore conducted to determine where the difference lie as shown in table 4 . The test result shows that the mean rating of Group A ( $\mathrm{M}=71.2)$ was significantly different from mean rating of Group B $(\mathrm{M}=$ $60.13)$ (mean difference $=11.07$ ) and also statistically significantly different from that of Group C $(M=56.63)$ (mean difference $=14.57)$. Similarly, the mean rating of Group $B(M=60.13)$ was significantly different from that of Group $C(M=56.63)$ (mean difference $=3.5$ ). 
Table 4: Tukey HSD Post-hoc comparisons test for post-intervention teaching skills mean ratings

\begin{tabular}{|c|c|c|c|c|c|c|}
\hline \multirow{2}{*}{$\begin{array}{l}\text { (I) } \\
\text { Microteaching } \\
\text { Group }\end{array}$} & \multirow{2}{*}{$\begin{array}{l}(\mathrm{J}) \\
\text { Microteaching } \\
\text { Group }\end{array}$} & \multirow{2}{*}{$\begin{array}{l}\text { Mean } \\
\text { Difference (I- } \\
\text { J) }\end{array}$} & \multirow{2}{*}{ Std. Error } & \multirow{2}{*}{ Sig. } & \multicolumn{2}{|c|}{$95 \%$ Confidence Interval } \\
\hline & & & & & Lower & Unner Bound \\
\hline \multirow[t]{2}{*}{$\overline{\text { Group A }}$} & Group B & $11.06667^{*}$ & 1.10562 & .000 & 8.4303 & 13.7030 \\
\hline & Group C & $14.56667^{*}$ & 1.10562 & .000 & 11.9303 & 17.2030 \\
\hline \multirow[t]{2}{*}{ Group B } & Group A & $-11.06667^{*}$ & 1.10562 & .000 & -13.7030 & -8.4303 \\
\hline & Group C & $3.50000^{*}$ & 1.10562 & .006 & .8637 & 6.1363 \\
\hline \multirow[t]{2}{*}{ Group C } & Group A & $-14.56667^{*}$ & 1.10562 & .000 & -17.2030 & -11.9303 \\
\hline & Group B & $-3.50000^{*}$ & 1.10562 & .006 & -6.1363 & -.8637 \\
\hline
\end{tabular}

*. The mean difference is significant at the 0.05 level.

Result displayed on table 5 also reveal that differences exist in the mean ratings of the pre-service teachers' teaching skills according to gender; however, the differences are not statistically significant $\mathrm{t}(88)=1.96, \mathrm{p}=.06$ (two-tailed). The eta squared statistic is (.04) which indicates a small effect size according to Cohen, (1988). Based on this result, the researchers fail to reject the null hypothesis of no significant difference in microteaching skills of pre-service teachers according to gender.

Table 5: T-test for equality of means of pre-service teachers on Microteaching skills by gender

\begin{tabular}{llllllll}
\hline S/No. & Gender & N & df & Mean & SD & t & Sig. \\
\hline 1. & Male & 28 & 88 & 65.14 & 8.6312 & 1.958 & .057 \\
2. & Female & 62 & & 61.53 & 6.7768 & & \\
\hline
\end{tabular}

**Indicates significant at 0.05 level

\section{Discussion}

The findings of this study have underscored the importance and need for microteaching in teacher preparation programmes. The microteaching intervention was found to enhance the teaching skills post-test scores of the pre-service teachers who took part in the experiment. This finding is in support of the findings of (Umeh, Mogbo \& Nsofor, 2015; Oscar, 2012). The result is also in support of Kilic (2010) that found a model of microteaching effective in improving teacher behaviours in all dimensions. It also resonates Remesh, (2013) assertion that as an innovative technique of training teachers to be effective, microteaching needs being implemented in teacher training institutions to help pre-service teachers to develop and nurture skills.

Copyright (C) International Association of African Researchers and Reviewers, 2006-2017: www. afrrevjo.net.

Indexed African Journals Online: www.ajol.info 
That the group which was treated to microteaching lessons with laboratory practice supported with digital video recordings and playback performed significantly better than the other two groups stresses the importance of the video recording and re-play in teaching skills acquisition. This result is in line with finding of Oscar (2012) that videotape recorder is a powerful tool that promotes effective teaching and learning in schools. The finding is also supported by the findings of Umeh, Mogbo and Nsofor, (2015); Shanu, (2016) and Savas, (2012) who reported the efficacy of video recordings in enhancing the English teaching skills of student teachers. This also buttresses the importance of the knowledge of immediate feedback dimension of microteaching as the student teacher were afforded the opportunity of watching their teaching and comparing it with the ideal situation which the theory of teaching has afforded him. The criticisms from peer and supervisor and self-assessment help the pre-service teacher to re-plan and invariably improve on the said skills. This finding is also in tandem with Programindaki and Arastırılması (2009) discovery that pre-service teachers feel motivated thereby gaining improved self-confidence with having the opportunity to observe themselves while gaining experience. If the teachers produced by the system are to be adequately equipped with good classroom teacher behaviours, then microteaching organised in a safe laboratory setting with relevant technologies need to be employed.

In the absence of the digital video recordings and playback, microteaching skills can still be significantly acquired if the teacher educators and peer criticise constructively after the teaching encounter. This is revealed by the finding that the group treated to microteaching without digital video recordings and playbacks performed significantly better than the conventional teaching group. Technology no doubt has added value to microteaching however strict adherence to the principles of microteaching without technology can produce acceptable results.

Gender was found to have no influence on the ability of the pre-service teachers to benefit from microteaching and use the appropriate teaching skills in practice. This result is at variance with Umeh, Mogbo and Nsofor, (2015) that report that males in the study group performed significantly better than the females in the group. The result however is in tandem with some other reports of studies on microteaching and the gender variable (Nwana, 2010; Ekpo-Eloma, Arikpo \& Ebuta, 2014; Shanu, 2016). The number of females in the teaching profession in Nigerian schools is a pointer to the fact that gender barriers may not be tenable. Both male and female pre-service teachers that took part in the study equally benefitted from the microteaching interventions.

\section{Conclusion}

The researchers have drawn the following conclusions from the research findings: 1 . Microteaching is an effective means of enhancing the teaching skills of trainee teachers; 2 . Technology can have great impact on microteaching practice as the use of

Copyright $($ C) International Association of African Researchers and Reviewers, 2006-2017: www. afrrevjo.net.

Indexed African Journals Online: www.ajol.info 
digital video recordings to provide knowledge of immediate feedback to the student teachers in the microteaching practice remains the most effective way to enhance their skills acquisition; 3 . Gender has no significant impact on student teachers' ability to benefit and acquire a repertoire of teaching skills from microteaching practice.

In conclusion, this study has provided empirical evidence to strengthen the need for the acquisition of the requisite teaching skills by student teachers through microteaching. The good teaching skills are not acquired in a vacuum but inculcated in the would-be teachers by seasoned faculty members who are more versed in teaching than the student teacher through modelling of its' use in the microteaching classrooms. Merely talking about effective teaching skills in conferences and seminars will not suffice in making pre-service teachers acquire them as these pre-service teachers are rarely part of most conferences and seminars. The most practicable way of doing these remains to demonstrate teaching of these skills by experts in the microteaching laboratory so that the pre-service teacher will learn and master them in a conducive and secure learning environment before they are to go into practice teaching in real life situations. The experts are therefore required to identify and isolate good teacher behaviours which a teacher in the 21 st century is expected to exhibit in order to achieve the goal of teaching in this millennium.

\section{References}

Abifarin, M. S. (2004). An insight to microteaching. Lagos: Inter-Venture Publishers Ltd.

Adedapo, A. (2013). Interactive effect of microteaching modes and learning styles on preservice teacher's practical teaching achievement; 34th International Proceedings of Nigeria Association for Educational Media and Technology (NAEMT) 1-355- 356.

Adewoyin, J. A. (2007). Fundamentals of educational technology. Ota: Artitude Communications Inc.

Anikweze, C. M. (1998). The place of self-evaluation in teaching at the NCE level. Review of Education. 15(1), 66-74.

Benton-Kupper, J. (2001). The microteaching experience: Student perspectives. Education, 121(4), 830-835.

Cohen, J. (1988). Statistical power analysis for the behavioral sciences (2nd ed.). Hillsdale, NJ: Lawrence Erlbaum Associates.

Cruickshank, D. R., Bainier, D., Cruz, J., Jr. Giebelhaus, C., McCullough, J. D., Metcalf, K. M., \& Reynolds, R. (1996). Preparing American teachers. Bloomington, IN: Phi Delta Kappa Educational Foundation.

Copyright () International Association of African Researchers and Reviewers, 2006-2017: www.afrrevjo.net.

Indexed African Journals Online: www.ajol.info 
Harvard University, Derek Bok Center for Teaching and Learning, (2006). What Is Microteaching? Retrieved September 11, 2015 from http://isites.harvard.edu/fs/html/icb.topic58474/microteaching.html

Ekpo-Eloma, E. O., Arikpo, A., \& Ebuta, C. N. (2014). Integrating video technology in micro-teaching sessions for teacher-trainees' self-appraisal and professional growth. Global Journal of Computer Science and Technology, 13(4) 25-28.

Elliot, J. (1982). A microteaching experiment at MEDUNSA. South African Medical Journal, 62(23), 868-870.

Esiobu, G. O. \& Maduekwe, A. N. (2008). Interactive and reflective learning using multi-media: Insights from preservice teachers' microteaching experience. Lagos: NAEMT Conference.

Fleiss, J. L. (1986). The design and analysis of clinical experiments. New York: John Wiley \& Sons.

Ghanaguru, S., Nair, P., \& Yong, C. (2013). Teacher trainers' beliefs in microteaching and lesson planning in a teacher training institution. The English Teacher, 52 (2)104-116.

Ifegbo, P. C. (2012). Microteaching: Purpose, process and content. Owerri: Cel. Bez Publishers.

Ijioma, B. C., Obasi, M. N., \& Ifegbo, P. C. (2014). Integrating microteaching theory+ practice in concurrent and consecutive teacher education programmes: Benefits and challenges. Rep Opinion, 6(9), 22-26.

Ike, G. A. (2017). Historical development and traditional practices of the concept of microteaching and macroteaching and their major advantages, In G. A. Ike. B. B. C. Onwuagboke, J. C. Anulobi and M. N. Ukegbu (Eds). Essential elements of Microteaching theory and practice. Owerri: Totan Publishers Ltd.

Keesee, G. S. (n.d.). Learning theories and instructional design technology Retrieved October 5, 2016 from http://teachinglearningresources.pbworks.com/w/page/19919565/Learning\%2 OTheories

Kilic, A. (2010). Learner-centred micro teaching in teacher education. International Journal of Instruction, 3(1) 77-100.

Lovegrove, M. N. (1975). Self-evaluation and staff evaluation of teaching practice performance. African Journal of Educational Research. 2(1), 1991-1995.

Copyright (C) International Association of African Researchers and Reviewers, 2006-2017:

www.afrrevjo.net.

Indexed African Journals Online: www.ajol.info 
AFRREV VOL. 11 (2), S/NO 46, APRIL, 2017

Mayhew, H. C. (1982). Developing teaching skills with microteaching. Unpublished manuscript, Secondary Education, University of Southern California, San Diego.

Nazir, R. (2011). Microteaching: Pilot Testing Precept. Retrieved October 7, 2015 from http://www.hec.gov.pk/InsideHEC/Divisions/LearningInnovation/Documents /Learning\%20Portal/Master\%20Trainer\%20(MT)/FPDP/Micro\%20Teaching/ Microteaching\%20ppt.pdf

Ohuche, R. O. \& Izuwah L. U. N. (1988). Microteaching and teacher effectiveness. Onitsha: Summer Educational Publishers Ltd.

Otsupius, I. A. (2014). Micro-teaching: A technique for effective teaching. African Research Review, 8(3), 183-197.

Passi, B. K. (1976). Becoming better teacher: Micro teaching approach. Ahmedabad: Sahitya Mudranalya.

Programındaki, A. M. Ö. Ö. Y., \& Araştırılması, E. (2009). A study on the effectiveness of peer microteaching in a teacher education program. Education and Science, 34(151), 165-174.

Remesh, A. (2013). Microteaching, an efficient technique for learning effective teaching. Journal of Research in Medical Sciences, 18(2), 158-163.

Savas, P. (2012). Micro-teaching videos in EFL teacher education methodology courses: Tools to enhance English proficiency and teaching skills among trainees. Procedia-Social and Behavioral Sciences, 55, 730-738.

Shanu, Y. M. (2016). Impact of microteaching video feedback on student-teachers' performance in the actual teaching practice classroom. International Journal of Instructional Technology and Distance Learning 13(11) 45-52.

Umeh, A. E., Mogbo, I. N. \& Nsofor, C. C. (2015). Effectiveness of video-tape recorder on micro-teaching on student teachers practice of stimulus variation skills. Journal of Educational Research and Reviews, 3(3), 32-36.

Wahba, E. H. (1999). Microteaching. English Teaching Forum Online, 37(4).

Wei, H. (2015). Microteaching lesson study: More than just practice teaching. Retrieved June 30, 2015 from http://researchnetwork.pearson.com/educatoreffectiveness/microteaching-lesson-study-just-practiceteaching\#sthash.ikyUCSVl.dpuf

Williams, P. (2010). Effective management of video-tape instructional materials in teaching and learning in secondary schools. J. Sci. Technol. Res. 7(8):34-42.

Copyright (C) International Association of African Researchers and Reviewers, 2006-2017:

www.afrrevjo.net.

Indexed African Journals Online: www.ajol.info 